\title{
Geomorphologic Features of Sataplia-Tskaltubo Limestone Massif
}

\author{
Tsikarishvili Kukuri ${ }^{1,}$, , Lezhava Zaza ${ }^{1}$, Asanidze Lasha ${ }^{1}$, Bolashvili Nana ${ }^{1}$, Chikhradze Nino ${ }^{1,2}$, \\ Chartolani Giorgi ${ }^{1}$
}

${ }^{1}$ Vakhushti Bagrationi Institute of Geography, Ivane Javakhishvili Tbilisi State University, Tbilisi, Georgia

${ }^{2}$ School of Natural Sciences and Engineering, Ilia State University, Tbilisi, Georgia

\section{Email address:}

kukuritsikarishvili@ymail.com (T. Kukuri)

\section{To cite this article:}

Tsikarishvili Kukuri, Lezhava Zaza, Asanidze Lasha, Bolashvili Nana, Chikhradze Nino, Chartolani Giorgi. Geomorphologic Features of Sataplia-Tskaltubo Limestone Massif. Earth Sciences. Special Issue: Modern Problems of Geography and Anthropology.

Vol. 4, No. 5-1, 2015, pp. 108-112. doi: 10.11648/j.earth.s.2015040501.30

\begin{abstract}
One of the important factors of karsto- and speleogenezis of Sataplia-Tskaltubo limestone massif is a still poorly studied geomorphological peculiarity of the region. Karsto- and speleogenezis is conditioned by the geological structure and tectonics. In the working process we used the already approved fundamental and applied research methods, both traditional and modern method systems. We carried out the detailed geomorphologic and karst-speleological exploration of the research area, conducted a large-scale survey works, on the basis of which we compiled the geomorphologic schematic map of Tskaltubo limestone massif and singled out the relief's genetic types.
\end{abstract}

Keywords: Speleology of Georgia, Karst Processes, Caves, Geomorphology, Limestone Massif

\section{The Research Territory and Methods}

Sataplia-Tskaltubo limestone massif is located in the northern zone of the Colchis Lowland's hilly relief and belongs to the Kvemo Imereti's speleological region [1]. In terms of geotectonics, the Tskaltubo limestone massif belongs to the Kutaisi sub block of the block of Georgia, which is built by the Middle and Upper Jurassic, the Lower and Upper Cretaceous and Paleogene, Neogene and Quaternary deposits.

Sharply expressed block structures of different scales with poorly represented plicate - brachifolded (short folds) dislocations, unimportant flexure-like depressions and etc., effusive magmatism manifestation and general litho- facial character of the Mesozoic-Cenozoic sedimentary rocks in the investigated territory and its adjacent area clearly indicate that territory is of block nature [2].

Karst phenomena intensity in the limestone massif and their unequal revelation is mainly related to the peculiarities of tectonic structure of the area. The latter, in turn, is caused by a tectonic nature, by uplift of Okriba - the area's main structural unit. Limestone massif development includes the western periphery of the Okriba uplift and is characterized by the south-eastern monoclinal fall, by a

sheet deposited on the crystalline basement located at a smaller depth and complicated subtransverse brachiform plicate dislocations of Ghvedi, Gelaveri, Lekouri and others.

Main feature of the region's tectonics is its two-tier structure. Mesozoic-Cenozoic sedimentary layers are represented in the Pre-Cambrian and Paleozoic crystalline rocks constructed on the solid substrate of Trans Caucasus block [3]. Tskaltubo limestone massif is entirely built of the Lower Cretaceous limestones and mainly are represented by basaltic Lower Neocomian several tens of meters of thick dolomite limestones of thick and medium layer, which gradually move into $150 \mathrm{~m}$ thick Barremian, massive thick-layered limestones of Urgonian facies. Southern monoclinal lying is characteristic to the structures, which contributes to the movement of underground waters to the mentioned direction.

Groundwater flow direction is also determined by the contact areas of karsting and nonkarsting rocks. There are very favorable hydro-meteorological conditions for karsting, which ensures the seasonal equality of karst-occurrence processes. The mentioned conditions promote the intensive development of karst phenomena throughout the year together with the high relative moisture [4]. During the spring heavy rains the water flows actively wash the soil nutrients. The clear evidence of it is the Opicho depression and cave-estavella emerged in its bed, 
which is the main area of discharge for the flows absorbed in the Melouri plateau.

Karst processes identify the major feature of the Tskaltubo limestone massif's relief. Karst landscape is perfectly expressed by the surface and underground forms. Slightly inclined surfaces are distinguished by the abundance of karst funnels, the genesis, types and morphometric data of which are quite diverse $[5,6]$. Especially widely distributed are the sinkholes or corrosive funnels with the waterabsorbtive ponors developed in the bottom (Fig. 1).

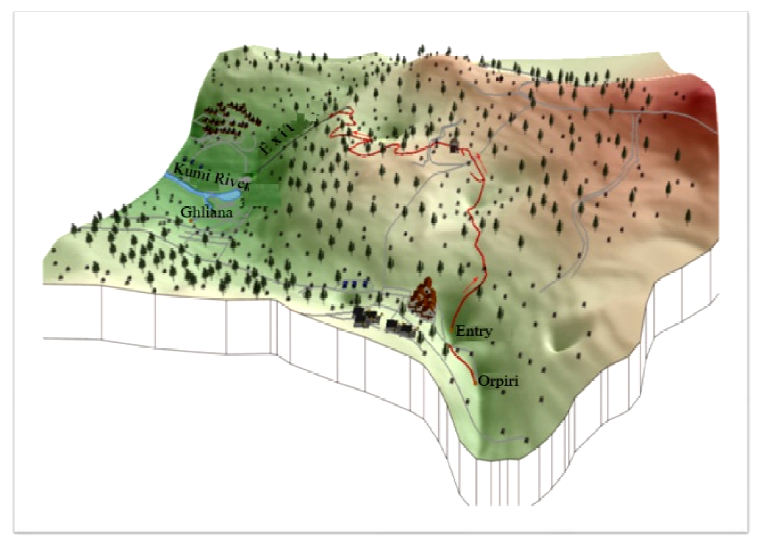

Figure 1. Block diagram of the Tskaltubo cave system (Author Giorgi Geladze).

Comparison of the schemes of aeroimage materials and inclination maps revealed that the frequency of distribution of the surface karst forms is highest on the slightly inclined surfaces and gradually decreases with the increasing the relief inclination. Layers of inclined lying cause the surface inclination as well, which affects the geomorphology of not only the funnels and Tskhunkuri and Kumistavi depressions, but the morphology of the karst surfaces emerged there. It is worth to attention the fact that the rapid flow of atmospheric precipitations occurs on the inclined slopes causing the weak expression of the surface karst-emerging phenomena. But the picture changes drastically in the flat surfaces.

The proof of it is the territory of the Melouri site located to the north of Tskhunkuri and, which actually distinguishes by the abundance of surface and underground karst forms. Large karst funnels, the ponors opened in their bottoms and the cave entrances are characteristic to the Melouri flat plateau. The same regularity has been observed in the right bank of the Semi River and the depression among the hills. There are $8-$ 10 funnels per $1 \mathrm{~km}^{2}$. Number of negative forms of the relief reaches 50 in the middle part of the research area. Their width varies within the 200-500 meters and the entries of the wells are presented in the bottom. Diameters of the karst funnels reach $50-60 \mathrm{~m}$ and $100-120 \mathrm{~m}$ in the lower zone or mainly to the east of the Tskaltubo Cave System.

Except funnels, the negative microforms (doors), temporal rivers, wells, shafts, horizontal "active" caves and etc. are widely represented in the massif characteristic to the bare karst. To the region's underground karst forms are characteristic the well-developed cavities with sharply expressed meander corridors and floors that evidence a slowdown in the upward movement or an important break in the development process. Cave forming scales in massif is determined by not only the thickness of karsting rocks, cracks frequency and openness, but the water storage under the ground and discharge conditions as well [7].

The massif is mainly characterized by the subhorizontal cavities of corrosion-erosion class with sharply expressed tires and labyrinths, which are geomorphologically sharply localized at contemporary or ancient erosion networks. They include the absorption, underground runoffs and discharge areas.

Different tectonic faults identify the cave directions. The most importantly distributed are the tectonic cracks $\left(260-270^{\circ}\right)$ of southwestern direction, which are accompanied by the main corridors of the caves. Crack crossings are usually associated with the emergence of large halls.

Discovered in $80 \mathrm{~s}$ of the last century Tskaltubo (Prometheus) cave system is worth noting among the explored caves in the area of the region, whose study is in progress for three decades. The total length of the surveyed corridors of the cave exceed $15 \mathrm{~km}$, but we expect this many tens of kilometers long, and perhaps, it is only a part of the even more extensive cave system. General contour of the Tskaltubo Cave is already clearly seen, which includes the area of about $15 \mathrm{~km}^{2}$ built by karsting rocks. On the basis of large-scale instrumental and semi-instrumental survey materials the three sections of this cave system are clearly identified. The upper section of the hydrokarst system includes the Bgheri, Didghele and Melouri caves; middle section includes Solkota, Satsurblia and sinkhole well; and the lower section includes the Opicho cave-estavella, crack siphon, Tskaltubo and Ghliana caves (Fig. 2).

Such a division is conditional. Indicative experiments of waters and geophysical observations confirm the unity of the system and existence of still unknown cave corridors creating complex labyrinth [8].

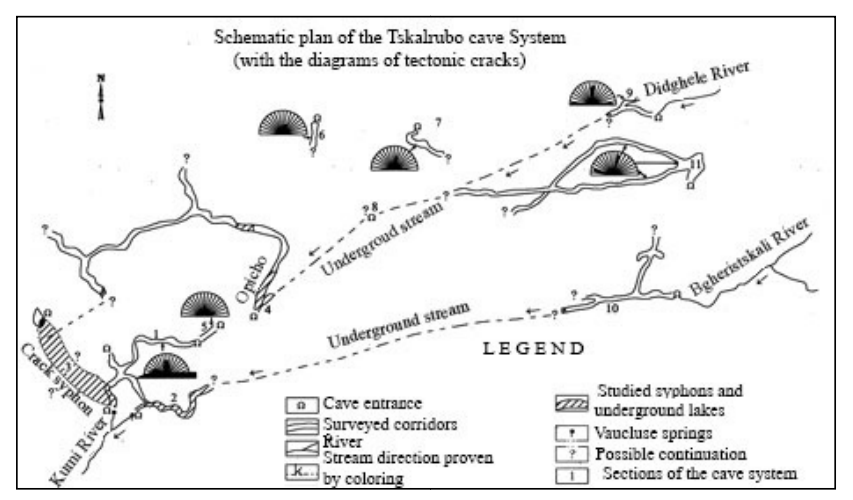

Figure 2. Schematic plan of the Tskaltubo cave system.

\section{The Research Goal and Results}

The research goal is the complete study of the research territory by speleo-geomorphological point of view. The contemporary limestone relief of the territory is a classic 
example of the influence of volcanic formations on karst processes. Surface and underground karst forms mainly were formed as a result of washing of igneous rocks.

In the development of cave system a certain role played the monoclinal structure of Samgurali Range, and in particular, the Turonian-Cenomanian volcanogenic shield. In this term, the Tskaltubo limestone massif is unique among the limestone massifs of Georgia.

Major role in the formation of groundwater systems play cyclic-tectonic impulses. For example, the depressions of various sizes distributed along the Semi River canyon at a relative height of 50-70 $\mathrm{m}$ are separated by their lower parts from the canyon with narrow crests. The rivers of mentioned depressions disappear in the ponors located at the foot of the crests. The flows that disappeared in such ponors beneath the Semi River bed, then drain towards the Tskaltubo Cave System.

Alluvium of different petrographical composition discovered in the Ghliana saddle is a proof of the fact that the main artery of the Tskaltubo cave system was conceived in this section from the very beginning and the waters mixed with each other in accordance of the tectonic pulses from the top down, left their traces in the form of saddles and caves. Such a process is depicted in the cave gallery as well. Having analyzed the accumulative relief of the Gubistskali River, we come to the conclusion that due to regressive accumulation the lower topographic levels and therefore all underground and surface forms turned out to be buried.

In the research region we have carried out large-scale surveying works, based on which we drew up the schematic geomorphological map of the Tskaltubo limestone massif and longitudinal section, and identified the following genetic types of the relief: tectonic, erosion and karst reliefs (Figures 3 and 4).

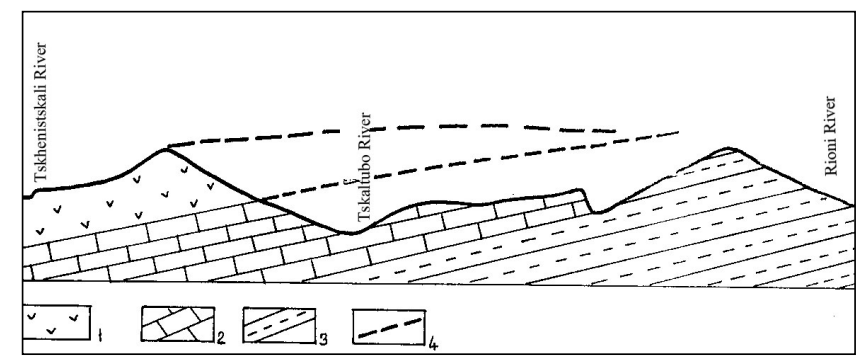

Figure 3. Longitudinal schematic section of the Tskaltubo limestone massif.

1. Erosion hills and hillocks developed on the Turonian-Cenomanian volcanogenic deposits;2. Karst relief on the Cretaceous deposits;

3. Erosion relief on the Jurassic deposits;4. Supposed location of stratigraphic floor.

Tectonic relief. As it is known, the Tskaltubo limestone massif is a western periphery of the Okriba tectonic arch (Valakhian orophase) and is complicated by the Ghvedi, Gelaveri, Lekouri (Pasadenian orophase) and other faults [3]. Basaltic dikes are intruded into the Turonian-Senonian layers, which often form the relief's positive forms. In their turn, these dikes control the direction of the underground cavities, and therefore, their orientation.

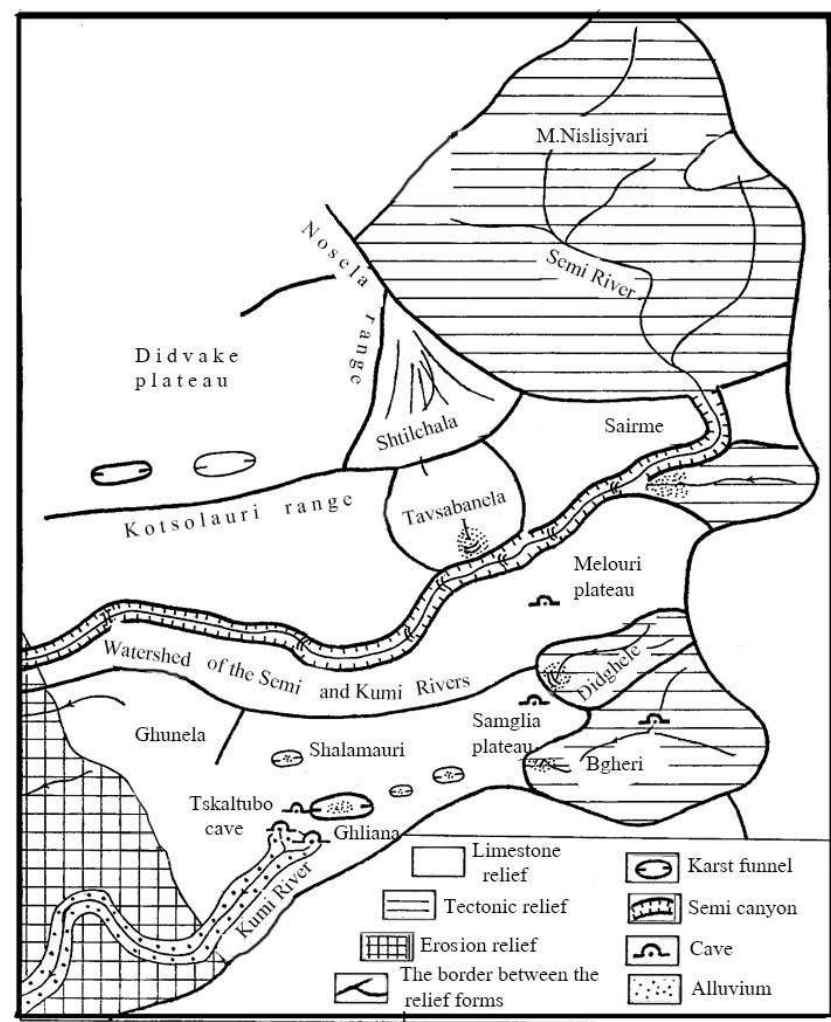

Figure 4. Geomorphological scheme of the Tskaltubo limestone massif.

Impact of Ghvedi and partially the Gelaveri fault is well-marked on the watershed of the Semi and Kumi Rivers, Melouri and Didvake plateaus. There are quite frequent tectonic disorders in the Semi River canyon. Another consequence of the Ghvedi fault is a Shtilichala grand landslide (length $1.5 \mathrm{~km}$; width of $2.0 \mathrm{~km}$ and a volume of 0.7 $\mathrm{km}^{3}$ ), which almost completely filled the depression of sublatitudinal direction. The Landslide mass flows over the watershed into the Tavsabanela depression located hypsometrically lower. Klastokarst phenomena are widespread on the landslide surface. Also the Sairme block was originated and sharply separated by the faults under the influence of tectonic dislocation. This block is surrounded by the rivers from all sides; they disappear under the ground at approaching the Semi River canyon and flow under the dry riverbed and then they flow to the direction of Tskaltubo cave system.

Erosion relief. The Tkaltubo limestone massif is surrounded by the narrow strip of the Jurassic deposits from the east and by the igneous rocks from the west. This space is an area of intense erosion.

Monoclinal composition of Samgurali range contributed to the intensification of denudation- erosion processes in the watershed section and thereby, to full movement of the limestone deposits. The Jurassic deposits outcrop on the surface because of mentioned reason and typical erosion relief is developed by forming the locked depression. Such depressions are surrounded by Urgon limestones from the western side. Erosion depressions' rivers disappear into the 
ponors located at the foot of the steep cliffs. Having passed through the entire limestone massif, they appear in the Colchis hydrogeological basin. On the monoclinal slope of the Samgurali range the rivers create a large network of subhorizontal cave systems, reaching the length of 2-4 km [9]. Among them the systems of Bgheri and Didghele galleries and the cave systems of Melouri and Samgle plateaus are distinguished. Waters of this large (2.6 square kilometers) Bgheri erosion depression originate the Kumi River. Alluvium located in the Ghliana watershed and within the Opicho and Tskalubo caves indicates that the development of these caves was going continuously from the top down according to the vertical circulation of the underground waters.

Karst relief. Tskaltubo limestone massif is divided into the Didvake monoclinal plateau, Samgurali monoclinal range and Tskaltubo depressions system, which in turn, are located at the foot of the mentioned relief forms.

The first two geographical units are developed at the highest altitudes and are the remains of the paleorelief. Didvake plateau $(700-800 \mathrm{~m})$ was previously cut from the intensive erosion-denudation area; therefore, its earlier structural form has been mainly preserved. The initial relief is heavily modified in the Samgurali range, where the limestone layer has been completely removed due to the intense erosion-denudation process and only the individual fragments have been remained in the form of peaks and former gorges. The erosion action continues even further but by less intensity. Sharp change of erosion processes with denudation (limestones intense karsting) should be caused due to the openning of volcanic cover [10].

Samgurali monoclinal range occupies relatively low hypsometrical location than the Didvake plateau $(550-600 \mathrm{~m})$ and includes the relief forms of a lower range. These are as follows:

1. Degraded paleodepressions with the limestone remainders in the watersheds and with the significant amount of limestone boulders located in the watershed basin;

2. Melouri flat-surface plateau, which is tightly connected to the Tskaltubo cave system by underground hydrological network. Powerful dealluvial layer deposited on the non-carbonate soil indicates that it is an erosion remainder of the igneous shield. Denuded remainders in the plateau (Konjgha, Chalistavi, etc.), as well as many large funnels (Ormukha, Solkota, Miona) and caves indicate wide scale distribution of the karst hollows. Also, the tectonics plays an important role in the development of caves;

3. Genetic analogy of the Melouri plateau is a Samglia-Blebi riparian limestone plateau, which exists thanks to dikes (artery-like geological body, which sharply differs from the building rocks). Influence of the Ghvedi fault is negligible there, accordingly, a western direction of the underground cavities is restored and the connection with the Tskaltubo Cave system is doubtless;

4. Watershed of the rivers of Semi and Kumi is heavily karsted in its central part (large funnels, Black Lake, floodplain, Satsurblia, Shalamouri, Koichala, etc.); and the topographical surface is sharply lower. Such a sinking is observed in the Ghunela flatland as well. These droppings of the south-western direction actually are the elongated linear-shaped and locked gorges. Water well observed in the Uglava large and locked gorge is also connected to the cave full of siphons;

5. Two-tier amphitheaters are of certain interest. Such morphological units often are of flat-bottomed and are separated from each other by the steep walls. There are shafts and wells in the bottom of each amphitheater. Stair-stepping is also characteristic to depressions, funnels and underground galleries. This circumstance is related to tectonic impulses and can be correlated with the surrounding terraces;

6 . Big role in the formation of underground systems belong to the cyclic tectonic impulses. For example, the various caves located at a relative height of 50-70 m along the Semi River canyon, with their lower parts are separated from the canyon by crests. The rivers of the mentioned cavities disappear into the ponors located at the foot of the crests. The flows disappeared in such ponors under the Semi River bed, drain towards the Tskaltubo Cave System.

Thus, the Tskaltubo cave system collects both the flows of Samgurali range and Didvake plateau, which are added by the streams leaked from Semi River.

\section{Discussion and Conclusion}

Cyclic-tectonic impulses play a major role in the formation of groundwater systems. E. g., the various caves located at a relative height of 50-70 m along the Semi River canyon, with their lower parts are separated from the canyon by crests. The rivers of the mentioned cavities disappear into the ponors located at the foot of the crests. The flows disappeared in such ponors under the Semi River bed, drain towards the Tskaltubo Cave System. Tskaltubo Cave system as it turns out, assemble the flows of the Samgurali range and Didvake plateau, which are added by the streams leaked from the Semi River [11].

Discovered in the Ghliana saddle the alluvium of different petrographical composition proves that in this section the main artery of the Tskaltubo Cave system was conceived from the very beginning and the waters were mixed with each other in accordance with the tectonic pulses, leaving their races from the top down in the forms of saddles and caves. Such a process is depicted in the cave Gallery itself. Having analyzed the accumulative relief of the Gubistskali River, we come to a conclusion that due to the regressive accumulation the lower topographic levels and therefore, all underground and surface forms turned out to be buried.

Against the background of the above mentioned positive forms of the relief, a different place occupies the Tskaltubo depression. The crucial role in its shaping played a powerful arc of volcanic formations, as a result of which the underground waters from the Samgurali range were gathered there, faced this dam and heading south. Water surge caused activation of erosion-denudation and lowering relief. None of the rivers could break this arc. Gradual movement of the hydrodynamical zone in the conditions of locked hydrological basin was made in the lower horizons, and accordingly - the 
lowering of the relief. These processes have been stalled since the erosion basis went down to the basaltic main layer. This has in its turn led to the accumulation of solid materials in the upper section of the Tskaltubo depression. Barrier effect of the main layer caused the congestion of the Tskaltubo Lake (erosion basis of the hydrogeological basin of the Tskaltubostskali River).

\section{References}

[1] Geomorphology of Georgia. 1971. "Metsniereba", Tbilisi, 609 p.

[2] M. Beridze, M. Kakabadze, O. Khutsishvili, et al. (1993). Geological conditions of karst system formation of Tskaltubo and adjacent areas. Tbilisi, p .30.

[3] Geology of the USSR. 1964. Vol. X.

[4] Sh. Kipiani, Z.Tatashidze (1963). Karst caves of Sataplia-Tskaltubo areas. In the book "The caves and the depressions of Georgia”. Vol. I, p. 25-64.

[5] K. Liponava 1990. Speleological news on Tskaltubo limestone massif. Proceedings of Geographical Society of Georgian SSR, vol. XVIII, p. 8-13.
[6] Z.Tatashidze, K.Tsikarishvili, J.Jishkariani, A.Jamrishvili, G. Geladze, G. Lominadze (2009). Tskaltubo Cave System. "Petite", Tbilisi, 72 p.

[7] J. Jishkariani., K. Tsikarishvili, T. Kobulashvili, et al. (1986). The latest results of Tskaltubo cave systems study. Vakhushti Bagrationi Institute of Geography Institute, Proseedings of the Final scientific session, p. 31-32.

[8] Z. K. Tatashidze, Jishkariani V. M., K. D. Tsikarishvili, et al. (2004). New karst cave in the vicinity of Tskhaltubo (western Georgia). Caves. Perm, p. 48-52. Georgia.

[9] J. Liponava (1985). Peculiarities of development of Tskaltubo limestone massif relief. "Problems of development of production forces of the mountainous areas". Proceedings, Tbilisi.

[10] K. Liponava (1987). Role of the volcanic formations in the development of Samgurali range karst relief. Vakhushti Bagrationi Institute of Geography. Proceedings of the scientific session, Tbilisi, p. 70-71.

[11] Tatashidze Z., Jishkariani J., Tsikarishvili K., Jamrishvili A., Kapanadze V., Kobulasvili T., Geladze G. (2002). Tskaltubo Cave System - the Largest Karst Depression in the Imereti Region. Bulletin of the Georgian Academy of Sciences, 166, № 3, p. 514-517. 